\title{
Rainwater treatment: an approach for drinking water provision to indigenous people in Ecuadorian Amazon
}

\author{
E. Pineda ${ }^{1} \cdot$ D. Guaya ${ }^{2} \cdot$ G. Rivera ${ }^{3} \cdot$ M. J. García-Ruiz ${ }^{4} \cdot$ F. Osorio ${ }^{4}$ (I)
}

Received: 14 May 2021 / Revised: 17 August 2021 / Accepted: 11 October 2021 / Published online: 28 October 2021

(c) The Author(s) 2021

\begin{abstract}
This study is about the use of naturally occurring filtering materials for rainwater treatment for drinking water proposal. Crushed gravel, ceramic spheres from natural clays, silica sand and natural zeolite were used as filtering materials. The mineralogical composition of filtering materials was determined, being the illite and mordenite the major components of ceramic spheres and natural zeolite, respectively. Naturally occurring materials were simultaneous evaluated on two configuration of pilot plant systems (biofilters) for rainwater treatment. Three columns were arranged in series with unstratified flooded beds. The first stage was packed using crushed gravel. The second stage was packed using ceramic spheres. The third stage was packed with silica sand for the first plant and a natural zeolite was used for the second pilot plant system. Finally, a last stage of ultraviolet disinfection was incorporated. The trial period was 90 days, and it was evaluated the removal of $\mathrm{Fe}^{+2}$ and $\mathrm{Mn}^{+2}$, total coliforms, faecal coliforms and Escherichia col (E. coli). The rainwater treatment system using natural zeolite provided better results than the one using silica sand at third stage. The concentration of $\mathrm{Fe}^{+2}$ and $\mathrm{Mn}^{+2}$ was below the maximum permissible limits within 45 days. The efficiency of the treatment systems was optimal within 45 days, after the efficiency decreased progressively. Then, it is an attractive proposal for rural areas in developing countries for singlefamily water treatment systems.
\end{abstract}

Keywords Rainwater treatment $\cdot$ Natural occurring minerals $\cdot$ Fe and Mn removal $\cdot$ Pilot plant

Editorial Responsibility: Samareh Mirkia.

F. Osorio

fosorio@ugr.es

1 Department of Geology, Mines and Civil Engineering, UTPL, Universidad Técnica Particular de Loja, Marcelino Champagnat Street, s/n, Barrio San Cayetano Alto, Loja, Ecuador

2 Department of Chemical, UTPL, Universidad Técnica Particular de Loja, Marcelino Champagnat Street, s/n, Barrio San Cayetano Alto, Loja, Ecuador

3 Degree in Biochemistry and Pharmacy, UTPL, Universidad Técnica Particular de Loja, Marcelino Champagnat Street, s/n, Barrio San Cayetano Alto, Loja, Ecuador

4 Department of Civil Engineering, Institute of Water, University of Granada, Spain, Ramón y Cajal Street, 4, 18071 Granada, Spain

\section{Introduction}

The contamination of water resources has become a serious problem. There is concern about the availability of water sources for human consumption in future (Rodell et al. 2018). Nowadays, around a thirty percentage of people do not have access to drinking water services and a sixty percentage do not have adequate sanitation systems (Sustainable and Goals 2019). People of developing countries, especially in rural areas, are susceptible to polluted water consumption.

The rural communities of the Ecuadorian Amazon region live in dispersed geographical locations. In these conditions is impossible to develop water supply systems for household consumption. The $71 \%$ of those inhabited areas use water from rivers and watercourses, which are polluted due to the lack of latrines since $38 \%$ of communities do not have access to sanitation services (Jokisch and Mcsweeney 2006). Moreover, the contamination from livestock, agriculture and the currently illegal artisanal mining activities pollute the surface water in certain areas of the Amazon. 
The inhabitants of Amazon areas collect and consume directly the rainwater, even it is stored in unhealthy conditions (Kim et al. 2017; Taffere et al. 2017). Rainwater is the unique source of water of some rural areas, being important their optimal use and conservation (Zhu et al. 2004). The collected rain water can be contaminated by dust particles, leaves and by the presence of animals (e.g. birds, cats and rodents) (Chidamba and Korsten 2015; Lee et al. 2016; Shaheed et al. 2017). The contamination of rainwater is promoted by containers without lids, the prolonged storage in dirty containers and the lack of maintenance of containers. The consequence is the development of microorganisms in water such as Total Coliforms (TC), Faecal Coliforms (FC) and Escherichia coli (E. coli) (Jesmi et al. 2014). Therefore, it is necessary to improve the quality of life of people from rural areas of developing countries.

Many technologies have been developed for water treatment at home which become effective for pollutants removal. Then, it is desirable a low-cost, easy operation and maintenance treatment system for rural areas (Ren and Smith 2013). Some low-cost materials have been used for purification purposes, such as the biochar obtained from agricultural by-products for heavy metals removal (Pineda et al. 2020). However, for rural areas it is appropriate the selection of a system without high energy consume that contribute to the environmental sustainability (Naddeo et al. 2013). In a previous work, a two-stage treatment system was developed for the water treatment collected from a ravine. A first stage of an up-flow aerated filter with ceramic carrier (sphere-type ceramics) was followed by a down-flow filter packed with silica sand (Pineda et al. 2021), where the selection of filtering materials was in accordance with the criteria of accessibility for the water purification system for the study zone.

In this study, natural occurring materials (e.g. gravel, clay and zeolite or silica sand) were used for the design and operation of two-pilot plants (PPs) for treatment of rainwater collected "in-situ" in the Ecuadorian Amazon. In the study area, the rainwater contains microorganisms of faecal origin, even though, the stored water is usually used by inhabitants for shower, laundry and dishwashing. So, the aim of this study is the development and evaluation of a low cost and easy operation system for rainwater treatment for rural areas of development countries where the access to safe water is desirable.

There were installed two-pilot plant systems using three biofiltration stages with ascending and descending flow. Also, an ultraviolet disinfection stage (UVD) was included for the rainwater microbial disinfection. The aims of this study were: (i) characterize the filtering materials, (ii) compare the performance of the two configurated treatment systems evaluating: iron $\left(\mathrm{Fe}^{2+}\right)$, manganese $\left(\mathrm{Mn}^{2+}\right)$, Total Coliforms (TC), Faecal Coliforms (FC) and Escherichia coli (E. coli) contents, (iii) control physicochemical parameters of water during treatment (e.g. $\mathrm{pH}$, temperature, total dissolved solids and dissolved oxygen), and (iv) performed an estimation of the economic viability of the proposed systems.

\section{Materials and methods}

The pilot plants (PPs) for water treatment were installed in a house of inhabitants of the Andean-Amazon border, south of Ecuador, coordinates $3^{\circ} 59^{\prime} 13.1^{\prime \prime} \mathrm{S} 79^{\circ} 11^{\prime} 49.3^{\prime \prime} \mathrm{W}$. In the study location, the average rainfall is around $1058 \mathrm{~mm}$ per year and it was classified as oceanic climate ( $\mathrm{Cfb}$ climate) according to the Köppen-Geiger climate classification system (Köppen and Geiger 1936). Then, rainwater was available throughout the study period due to recurrent rainfall of the area. The rainwater collection was performed continuously within 90 days of the trial period. Rainwater was collected "in-situ" from the asbestos cement roofs and runoff water of courtyard of houses of indigenous people of the zone. Traditionally, the inhabitants of the study area have already adapted this collection system in their houses. Conventionally, the existent fauna of the zone surrounds houses so easily it can be found bird and rodents manure that change the original quality of rainwater, accompanied by soil particles, leaves and other solids existent on the zone. The use of a textile filter mesh during rainwater collection was proposed as an alternative to avoid the presence of large solid particles (e.g. soil, manure, leaves, etc.); however, it does not limit the microbiological contamination.

The World health organization recommend a minimum water supply requirement of $7.5 \mathrm{~L} /$ inhabitant/day WHO (2017), so it was established a supply of 10 L/inhabitant/ day. A typical Amazonian Shuar rural family of 5 people was considered for household in Ecuador. So, the daily water requirement for this family was determined as 50 L/day.

The pilot plants were designed based on the biofiltration principle which is optimal for reducing physical, chemical and biological parameters in water. Being odour, colour, taste, dissolved metals and biological pathogens the main parameters to be controlled (CAWST 2011).

The experimental system was adapted using a dark polyethylene tank (capacity of $1200 \mathrm{~L}$ ) for rainwater storing. It was using a peristaltic pump (Masterflex L/S, pump workflow range: $2.8-1700 \mathrm{ml} / \mathrm{min}$ ) and a silicone duct (internal diameter $06.4 \mathrm{~mm}$ ). The flow of the influent of the rainwater was established as $1.6 \pm 0.2 \mathrm{~L} / \mathrm{h}$ equivalent to a filtration rate $0.1 \mathrm{~m} / \mathrm{h}$ for both pilot systems PP1 and PP2. This system was formed by three serial stages using polyvinyl chloride columns (PVC, internal diameter $152 \mathrm{~mm}$ and height $100 \mathrm{~cm}$ ) according to the configuration depicted in Fig. 1.

According to United States Environmental Protection Agency EPA (2018) recommendation laboratory scale systems for water treatment should be covered of external 

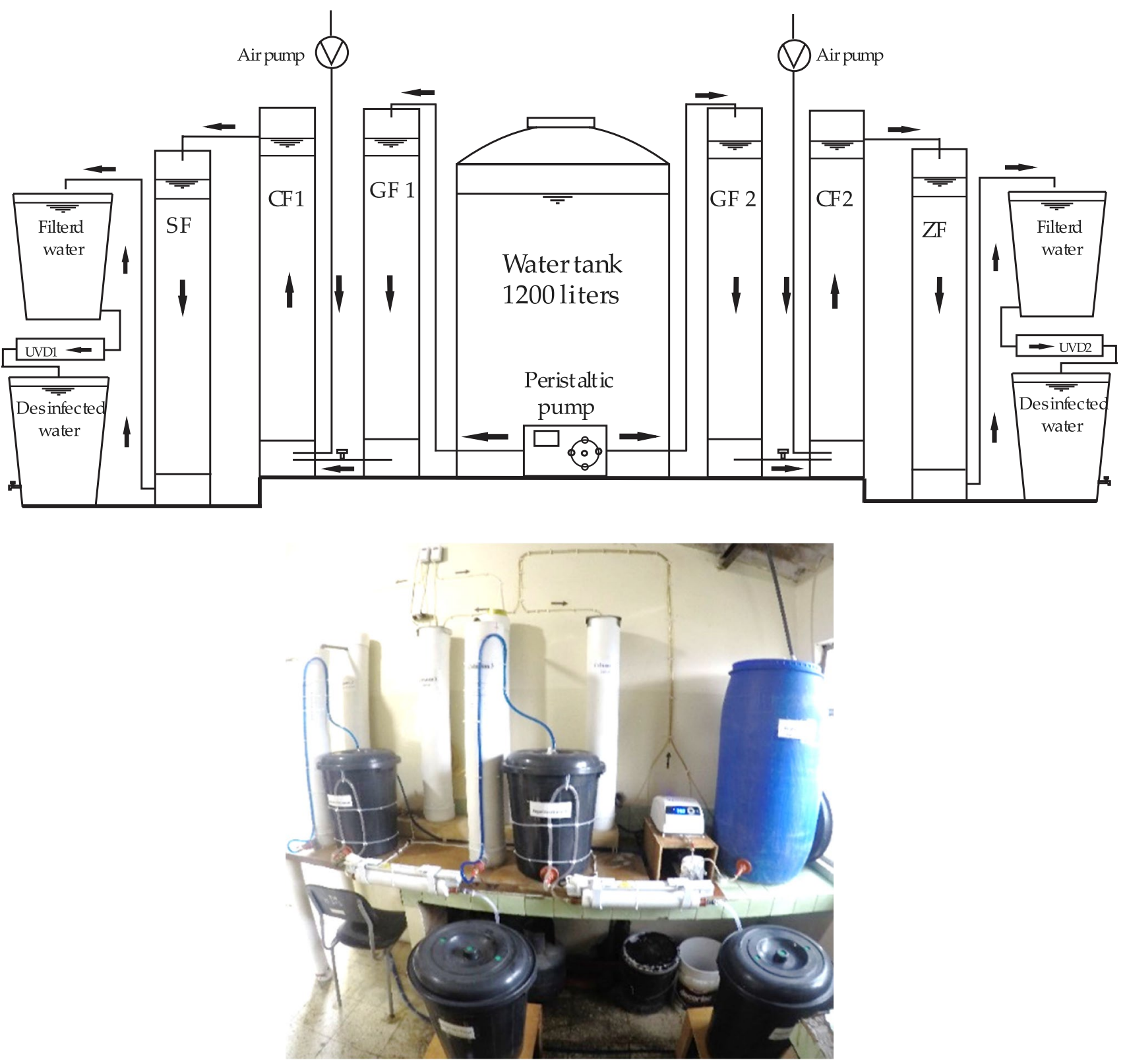

Fig. 1 Pilot plant to purify rainwater at a single-family level in the rural sector, with a capacity to purify $50 \mathrm{~L} /$ day

agents. Then, sunlight and wind that assist the reproduction of algae and pathogens may alter the system's efficiency. So, not transparent PVC columns were built and located inside the house to protect them for external agents.

Three columns of rainwater treatment were arranged in series for each two-pilot plant system. The first stage was packed using crushed gravel. The second stage was packed using ceramic spheres. The third stage was packed with silica sand for the first plant and a natural zeolite was used for the second pilot plant system. Finally, a last stage of ultraviolet disinfection (UVD) was incorporated.
The efficiency of each treatment stage was related with the prior stage, evaluating the concentration of the effluent in comparison with the influent. It was registered information about each stage and its contribution to the pollutant's removal.

\section{First stage: gravel filter (GF)}

The gravel filter system was configured downstream. It was packed with gravel (average diameter $5 \mathrm{~mm}$ ) with thick filter for sieving purpose. The gravel was collected from a quarry from the study area. The gravel filter (GV) was separated 
$10 \mathrm{~cm}$ from the bottom of the column by using a diffusion layer. A perforated plate was placed on supports fixed to the column wall. This space was established to avoid deposition of solids at the bottom and simplify the purge. The total height of the system was $100 \mathrm{~cm}$. The filter bed occupied $75 \mathrm{~cm}$. It was established $5 \mathrm{~cm}$ of flood layer at the top the column.

\section{Second stage: ceramic spheres filter (CF)}

The ceramic filter was configured by ascending flow. The ceramic filter was packed with ceramic spheres (average $13 \mathrm{~mm}$ in diameter) obtained from a natural clay. The clay was obtained from the geological formation 'Zamora' (coordinates $-4.191515,-79.280533$ ), and it was coded as CZ. The clay granulometry, liquid limit (LL), plastic limit (PL) and plasticity index (PI) were determined (ASTM D 4318 2016). The clay material was pulverized and mixed with water for clay spheres elaboration. The clay spheres were dried at room temperature $\left(20 \pm 2{ }^{\circ} \mathrm{C}\right)$. The spheres were calcined at $850^{\circ} \mathrm{C}$ for $2 \mathrm{~h}\left(\right.$ at $5{ }^{\circ} \mathrm{C} / \mathrm{min}$ rate) (Ajayi and Lamidi 2015; Wang et al. 2016). It was used a column configuration similar to that of GF column. The water and atmospheric oxygen is induced in this column once the system is running, using oxygen at ascending flow rate of $5 \mathrm{~L} / \mathrm{min}$ ( $35 \mathrm{~W} \mathrm{JAD}$ compressor, model ACQ-003) (Khadse et al. 2013).

\section{Third stage: silica sand filter (SF) or natural zeolite (ZF)}

Silica sand and natural zeolite (average diameter $2 \mathrm{~mm}$ ) were used for the third column stage. The silica sand filter was coupled to the pilot plant PP1 while the natural zeolite filter was coupled to pilot plant PP2. Both columns received the treated water from the ceramic filters $\mathrm{CF} 1$ and $\mathrm{CF} 2$, respectively. The silica sand and natural zeolite filter bed occupied $75 \mathrm{~cm}$. It was established $5 \mathrm{~cm}$ of flood layer at the top the column to ensure the formation of the biological layer. The effluent was temporally stored in a tank (capacity $60 \mathrm{~L}$ ).

\section{Ultraviolet disinfection (UVD)}

A final stage of treatment was established using Ultraviolet Disinfection (UVD) for the microbial removal from the filtered water. It was used an artisanal system incorporating a $250 \mathrm{~nm}$ UV lamp tube (wavelength range from 240 to $280 \mathrm{~nm}$ ) (Masschelein 2012). The UV lamp was adapted horizontally in pipeline (opaque PVC pipe with diameter $63 \mathrm{~mm}$ ) and closed at both extremes. An inlet pipeline $(12 \mathrm{~mm})$ and an outlet pipeline $(18 \mathrm{~mm})$ were coupled to the UVD stage to ensure a continuous rainwater layer. It was used an operation thickness of rainwater layer $(1.8 \mathrm{~cm}$ approximately) that requires a minimum length $(40 \mathrm{~cm}$ accordingly to the UV lamp length) to assure an optimal UV radiation reaction time (Thomas and Burgess 2013).

\section{Characterization of the filtering materials}

The chemical properties of the filter material were analysed in a Bruker Corporation X-ray Fluorescence (XRF) equipment, S1 Turbo model, Mining Light Elements measurement method. The mineralogical composition was determined on a D8-Advance X-ray diffractometer, Bruker Corporation brand, with a copper tube with Ka wavelength $(1.5418 \AA)$ (Semiz 2017; Souza et al. 2014). The physical properties of filter materials (e.g. granulometry, densities, specific gravity, pore sizes, compressive strength, and Atteberg limits) were also determined according to the ASTM D 4318 standard (ASTM D 4318 2016).

\section{Effluent analysis}

Samples of the treated rainwater (at least six samples of effluents) of each stage from both treatment systems were collected every 15 days. The collected treated water samples were filtered on a $45-\mu \mathrm{m}$ filter paper. The concentration of iron and manganese was determined by an inductively coupled plasma spectrometry equipment (ICP-MS, Optical Emission Spectrometer 8000). The $\mathrm{pH}$ was measured using a portable potentiometer (CRISON pH 25, CRISON Instruments, Spain). The dissolved oxygen was measured using a portable oximeter (Crison OXI 320). It was also measured the temperature and total dissolved solids (KETOTEK TDS). The culture medium ColiBlue24 Broth M00PMCB24 was used for bacterial growth (Total coliforms and E. Coli) determination. This culture medium contained inhibitors that prevent the growth of non-coliform bacteria. It was used an incubation time of $24 \mathrm{~h}$ at $35^{\circ} \mathrm{C} \pm 1$ with $\mathrm{pH}$ of $7.0 \pm 0$. The Broth MHA000P2F m-FC culture medium with rosolic acid was used for faecal coliforms determination. It was used an incubation time of $24 \mathrm{~h}$ at $44.5^{\circ} \mathrm{C} \pm 1{ }^{\circ} \mathrm{C}$ with a pH of $7.4 \pm 0.2$ (Millipore 2018). The culture media were incubated at $35{ }^{\circ} \mathrm{C} \pm 0.5$ ) for $24 \mathrm{~h}$. The counting was performed in a stereomicroscope (Stemi DV4, ZEISS, Germany) with a magnification of $4 x(0.8 x / 3.2 x)$.

\section{Results and discussion}

\section{Characterization of the filter materials}

The filter materials chemical composition and mineralogical composition is depicted in Table 1.

The gravel a silica are mainly $\mathrm{SiO}_{2}$. The specific gravity of gavel was $2.9 \mathrm{gr} / \mathrm{cm}^{3}$. The granulometry of gravel 
Table 1 Chemical and mineralogical composition of the filtering materials

\begin{tabular}{|c|c|c|c|c|c|}
\hline & Raw clay & Clay spheres & Gravel & Sand & Zeolite \\
\hline \multicolumn{6}{|c|}{ Chemical components (\%) } \\
\hline $\mathrm{SiO}_{2}$ & 59.9 & 58.6 & 97.5 & 96.8 & 61.4 \\
\hline $\mathrm{Al}_{2} \mathrm{O}_{3}$ & 29.6 & 28.5 & 0.5 & - & 23.9 \\
\hline $\mathrm{Fe}_{2} \mathrm{O}_{3}$ & 4.3 & 6.2 & 0.3 & 0.2 & 0.4 \\
\hline $\mathrm{K}_{2} \mathrm{O}$ & 4.6 & 4.0 & 0.2 & - & - \\
\hline $\mathrm{TiO}_{2}$ & 0.7 & 0.8 & - & 0.7 & - \\
\hline $\mathrm{CaO}$ & 0.1 & 0.2 & - & - & - \\
\hline $\mathrm{Na}_{2} \mathrm{O}$ & 0.2 & 0.3 & - & - & - \\
\hline \multicolumn{6}{|c|}{ Mineralogical components (\%) } \\
\hline Quartz & 30.6 & 24.8 & 98 & 99 & 33.1 \\
\hline Albite & - & 12.4 & - & - & 1.2 \\
\hline Illite & 46.2 & 62.8 & - & - & - \\
\hline Faujasita Ca & 1.0 & - & - & - & - \\
\hline Kaolinite & 22.2 & - & - & - & - \\
\hline Calcite & - & - & - & - & 8.6 \\
\hline Biotite & - & - & - & - & 4.7 \\
\hline Montmorillonite & - & - & - & - & 5.9 \\
\hline Mordenite & - & - & - & - & 46.6 \\
\hline \multicolumn{6}{|c|}{ Physicochemical characteristics } \\
\hline $\begin{array}{l}\text { Specific surface } \\
\left(\mathrm{m}^{2} / \mathrm{g}\right)\end{array}$ & 10 & & & & \\
\hline
\end{tabular}

determined a clay content of $4.9 \%$, silt of $46.9 \%$ and sand of $48.2 \%$.

The clay material was mainly composed by $\mathrm{SiO}_{2}, \mathrm{Al}_{2} \mathrm{O}_{3}$ and $\mathrm{Fe}_{2} \mathrm{O}_{3}$. The clay with high plasticity had a specific surface area of $10 \mathrm{~m}^{2} / \mathrm{g}$, lower than other raw clay reported for organic removal compounds (Dammak et al. 2013). The diameter of the ceramic spheres was $13 \mathrm{~mm}$. The weight and the volume of the spheres were $1.9 \pm 0.1 \mathrm{~g}$ and a $1.3 \pm 0.1 \mathrm{~cm}^{3}$, respectively. The porosity of the ceramic spheres was $35.3 \pm 13.5 \%$. A porosity greater than $30 \%$ contributes to support bio-mass material, so clay spheres are suitable for the filtration process (Yuan et al. 2013). The density of ceramic spheres was $2.0 \pm 0.9 \mathrm{gr} / \mathrm{cm}^{3}$. A compressive strength of $2.6 \pm 1.2 \mathrm{~kg} / \mathrm{cm}^{2}$ and the pore size was $7.7 \pm 1.9 \mu \mathrm{m}(\max .10 \mu \mathrm{m}$ and $\min .5 \mu \mathrm{m})$.

Quartz, Illite and Kaolinite were determined in the raw clays as the major mineral phase. The faujasite-Ca was detected in low content in raw clay. In the ceramic spheres were determined albite as new mineral phase as consequence of the calcination process (Ajayi and Lamidi 2015). The SEM analysis shows a lamellar morphology typical of clays (Fig. 2), and it can be seen remains of sedimentary rocks and quartz, boulders and clays.

The sand developed a specific gravity of $2.7 \mathrm{gr} / \mathrm{cm}^{3}$ and volumetric weight of $2.6 \mathrm{gr} / \mathrm{cm}^{3}$. The humidity and porosity of sand was $1.5 \%$ and $5.0 \%$, respectively. The zeolite was composed by $\mathrm{SiO}_{2}, \mathrm{Al}_{2} \mathrm{O}_{3}$ and $\mathrm{Fe}_{2} \mathrm{O}_{3}$. Quartz and mordenite were determined as the main major mineral phase of zeolite. The natural zeolite had a moisture retention capacity of $42.9 \%$. The porosity and real density were $39 \%$ and $1.7 \mathrm{~g} / \mathrm{cm}^{3}$.

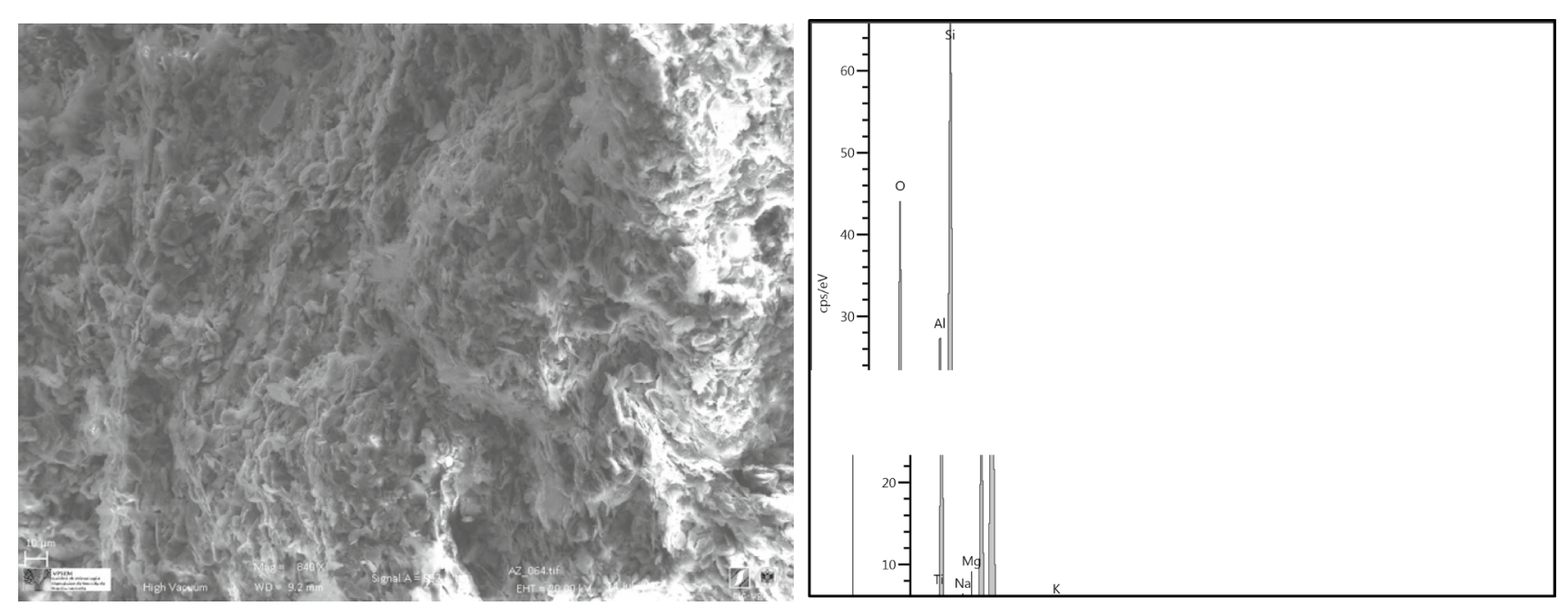

\begin{tabular}{|l|l|l|l|l|l|l|l|l|l|}
\hline Element & $\mathrm{O}$ & $\mathrm{C}$ & $\mathrm{Si}$ & $\mathrm{Al}$ & $\mathrm{Fe}$ & $\mathrm{K}$ & $\mathrm{Mg}$ & $\mathrm{Ti}$ & $\mathrm{Ca}$ \\
\hline Wt (\%) & 43.43 & 11.32 & 24.16 & 9.07 & 6.67 & 2.40 & 1.00 & 0.88 & 0.63 \\
\hline
\end{tabular}

Fig. 2 SEM images of raw clay 


\section{Operation characteristics}

The pilot plants operated within 90 days, and a residence time of $3.2 \mathrm{~h}$ was determined for the filter bed columns. The registered data of the temperature at each stage of pilot plants are depicted in Fig. 3. The average temperature of all treatment stages of the system was recorded at $18.9 \pm 1.5^{\circ} \mathrm{C}$. Exceptionally, in the CFs it was recorded an average temperature of $17.5 \pm 1.5^{\circ} \mathrm{C}$. The decrease of temperature in the $\mathrm{CF}$ column was effect of the mechanical aeration which promotes evaporation in the air-water interface. The ceramic material also performed a thermal insulator function. Sometimes, the decrease of the effluent temperature has been associated with a decrease of microbial enzymes which affects the oxidation and decomposition of contaminants. In this study, a slight variation of temperature was determined but it was not associated an efficiency reduction as consequence. It has been also reported in previous works the increase of viscosity with the temperature decreasing, promotes the deficit in the sedimentation of particles and then a reduction in the removal of contaminants (Tekerlekopoulou et al. 2013); but due to the slight variation of temperature in the different stages this effect was not perceptible.

Rainwater is stagnated so it is necessary the aeration. Atmospheric oxygen is induced in the CF column to increase

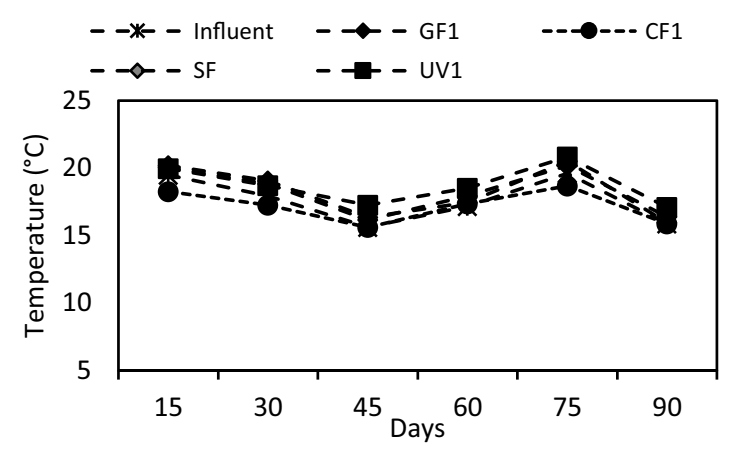

Fig. 3 Temperature data trend during 90-day trial period

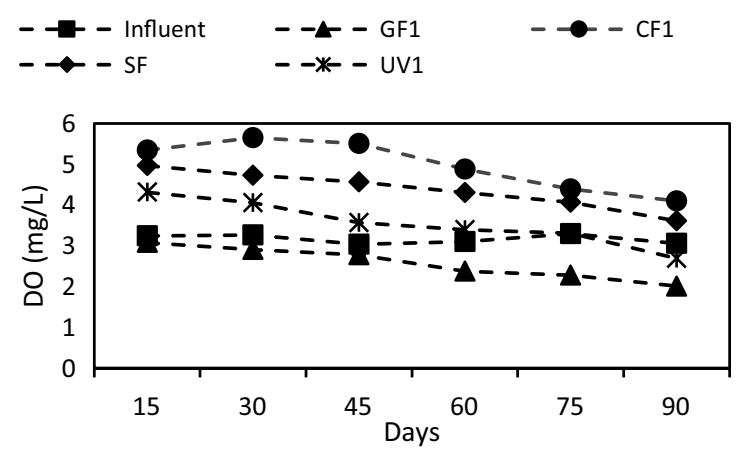

the dissolved oxygen (DO) concentration in water (Khadse et al. 2013). The registered data of the dissolved oxygen content at each stage of pilot plants are depicted in Fig. 4. The increase of dissolved oxygen content will provide the optimal conditions to the filter to promote the growth of microorganisms on the surface of clays spheres. The formation of this biofilm improved the water purification action of the filter due to the biodegradation of pollutants (Qian et al. 2021). The DO content of treated water increased since the CFs stage and it was remained until at the UVD system outlet. Then, a slight increase of temperature (5\% approximately) occurred and the DO content reduced 20\% approximately within the trial period. The reduction of DO sometimes has been associated with the saturation of the system as effect of the time of use (WHO 2017). However, a good $\mathrm{Fe}^{2+}$ and $\mathrm{Mn}^{2+}$ and microbial removal was performed by the PPs as it will be discussed in the following sections.

The registered data of the $\mathrm{pH}$ values at each stage of pilot plants are depicted in Fig. 5. The pH value of the effluent of the pilot systems is used in this study in an acceptable range (7-8), which is between the minimum and maximum permissible limit (6.5-8.5) for drinking water (NTE INEN 1108 2014). It has been also reported that $\mathrm{pH}$ of water between $\mathrm{pH}$ 6-9 is suitable for growth and operation of biofilms (Patil et al. 2011).
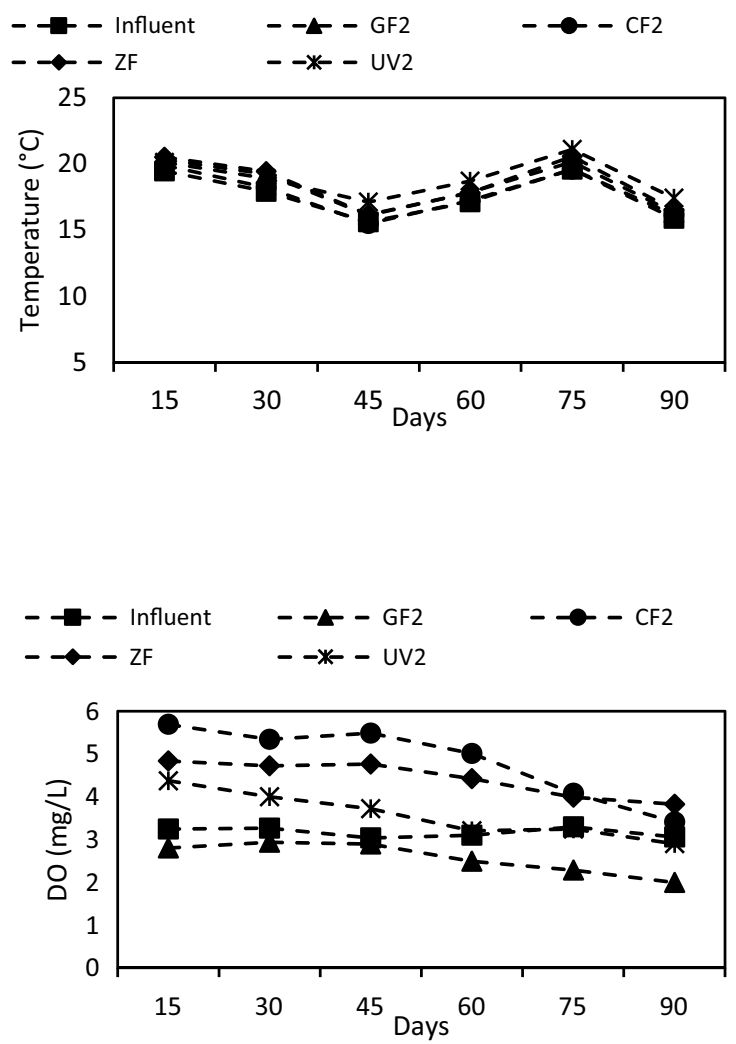

Fig. 4 Registered DO values of influent and treated rainwater at each stage of treatment of both PP1 and PP2 over the 90-day trial period 

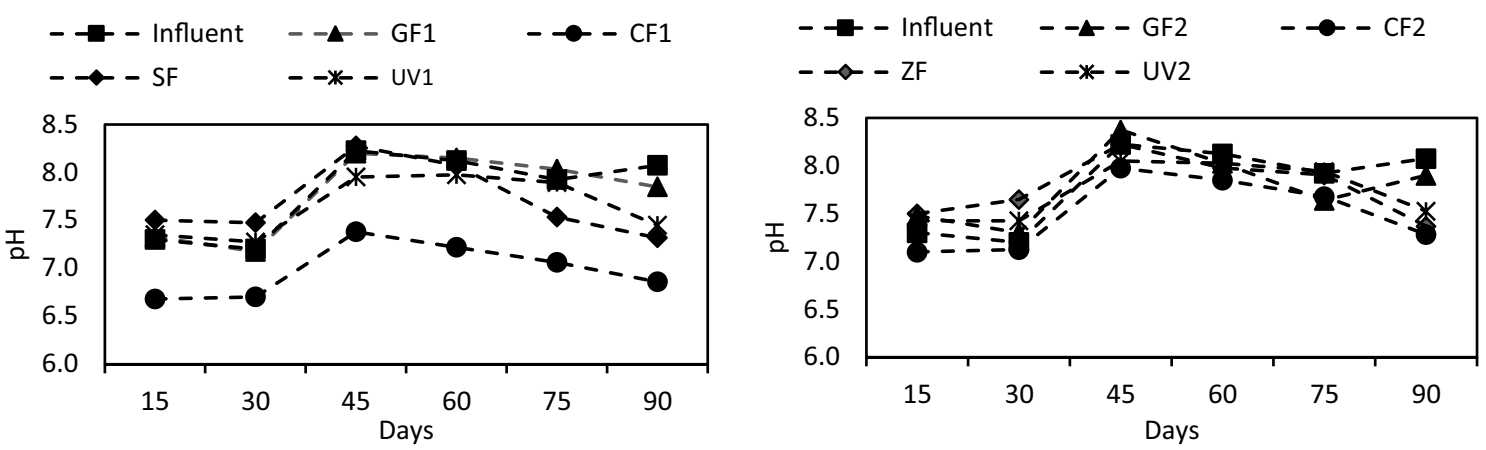

Fig. 5 Registered $\mathrm{pH}$ values of influent and treated rainwater at each stage of treatment of both PP1 and PP2 over the 90-day trial period

The registered data of the total dissolved solids (TDS) at each stage of pilot plants are depicted in Fig. 6. The total dissolved solids (TDS) content of water in the influent is $\sim 7 \%$ lower than the effluent from UVD stage within 30 days of continuous functioning. The release of some solids from the filtering material occurred during the pilot plants operation. However, after 30 days of operation it can be seen the increase of TDS of rainwater influent and effluent of each stage. Nevertheless, the TDS content is lower than $1000 \mathrm{mg} / \mathrm{L}$ which is the maximum permissible value, so it will not developed a unpleasant taste of water for the consumer (NTE INEN 1108 2014; WHO 2017), since TDS is a parameter of water quality that describes the inorganic salts present in solution in water.

\section{Removal of $\mathrm{Fe}^{2+}$ and $\mathrm{Mn}^{2+}$ in rainwater}

The collected rainwater comes mostly from the roof of the houses and from surface runoff. After carrying out a characterization of the collected rainwater, the presence of iron and manganese was verified as the most relevant physical-chemical pollutants. Hence, iron is of the most important element of soils from the Ecuadorian Amazon region whose mobility and dynamic depends on the several factors (e.g. pH, altitude, etc.). In this study, we believe the action of the wind that carries solid particles that settle on the roof surface affect the original rainwater composition. The presence of excessive iron and manganese in rainwater originated in natural minerals from the soil and dissolved in rainwater has been reported in previous works (Aziz et al. 2020; Ebraheim et al. 2021).

The World Health Organization WHO (2017) has established the permissible contents for $\mathrm{Fe}^{2+}$ at $0.3 \mathrm{mg} / \mathrm{L}$ and for $\mathrm{Mn}^{2+}$ at $0.2 \mathrm{mg} / \mathrm{L}$. In Fig. 7a, b, it was depicted the reduction of $\mathrm{Fe}^{2+}$ and $\mathrm{Mn}^{2+}$ content, respectively, at each stage of the treatment systems. It was compared with the maximum permissible limits for human consumption. The $\mathrm{Fe}^{2+}$ and $\mathrm{Mn}^{2+}$ content of the influent was compared with the effluent of each stage of filtration.

Pilot plant PP1 removes $\mathrm{Fe}^{2+}$ until up to $79 \%$ in the first 15 days, but the efficiency decreased to $68 \%$ at 90 days. The pilot plant PP2 removed $87 \% \mathrm{Fe}^{2+}$ within 15 days, but the efficiency decreased to $68 \%$ at 90 days. Then PP2 efficiency was higher than PP1. The $\mathrm{Fe}^{2+}$ removal efficiency of by filter columns in the PP1 was in the following order: (CF $\approx 58 \pm 5 \%)>(\mathrm{SF} \approx 28 \pm 6 \%)>(\mathrm{GF} \approx 14 \pm 4 \%)>(\mathrm{UVD} 1$ $\approx 3 \pm 1 \%)$ and for the PP2: $(\mathrm{CF} \approx 58 \pm 6 \%)>(\mathrm{ZF} \approx$ $43 \pm 5 \%)>(\mathrm{GF} \approx 15 \pm 4 \%)>(\mathrm{UVD} 1 \approx 2 \pm 1 \%)$.
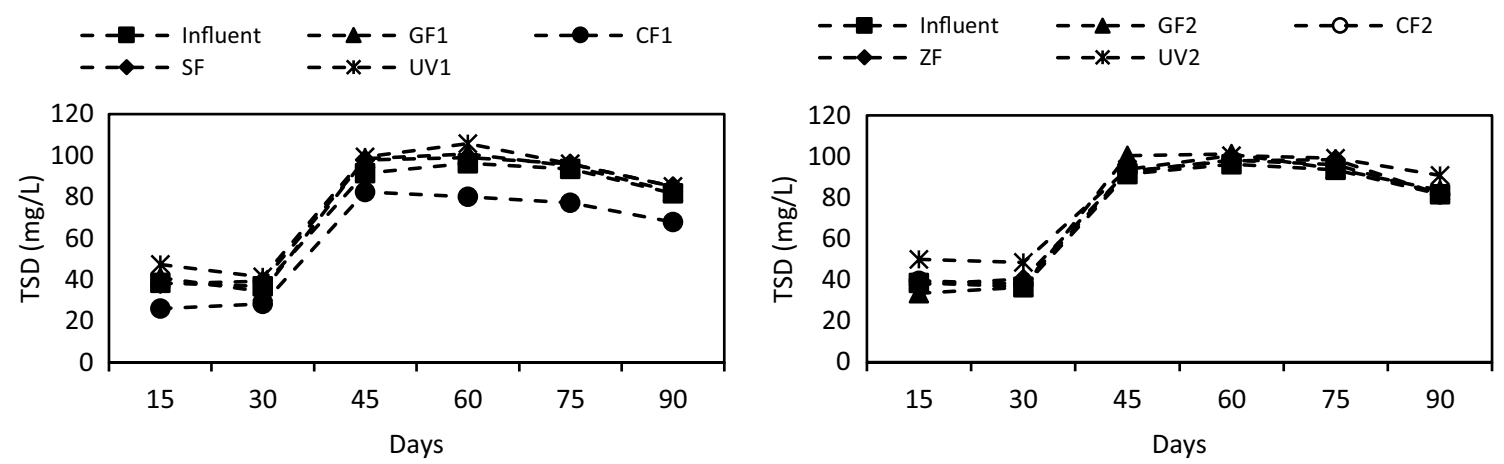

Fig. 6 Registered total dissolved solids content of influent and treated rainwater at each stage of treatment of both PP1 and PP2 over the 90-day trial period 

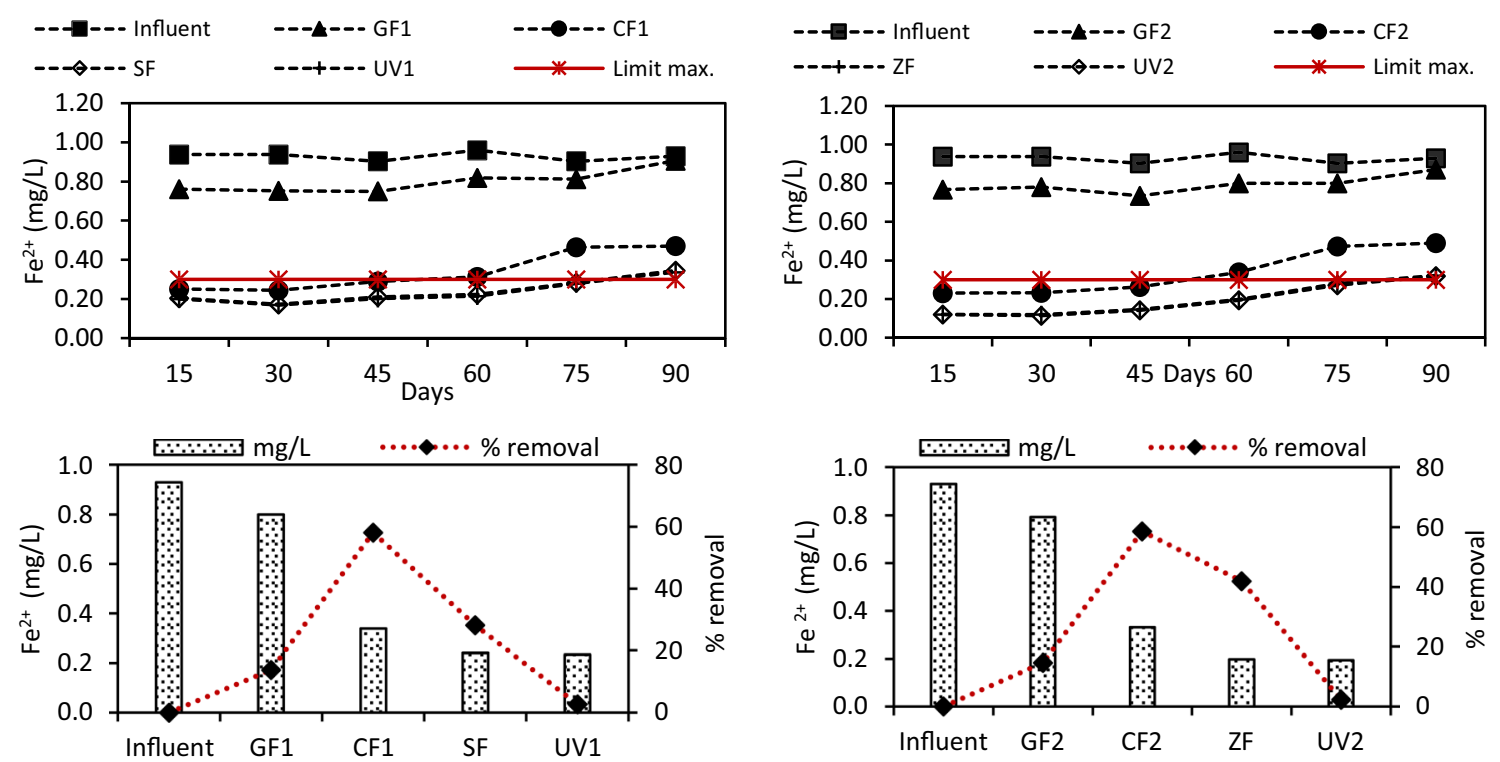

(a)
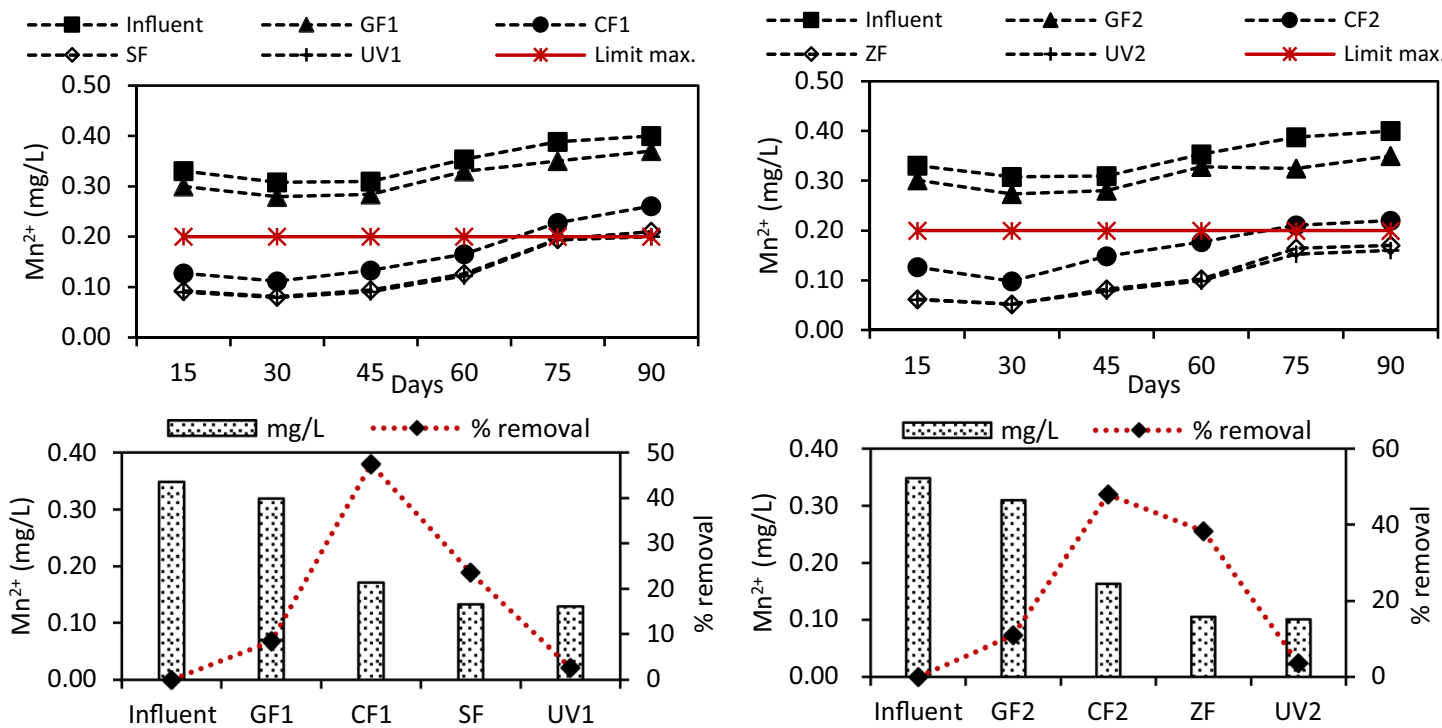

(b)

Fig. 7 Removal of $\mathrm{Fe}^{2+}$ and $\mathrm{Mn}^{2+}$ over the 90-day trial period. a Removal of $\mathrm{Fe}^{2+}$ b Removal of $\mathrm{Mn}^{2+}$

The removal of $\mathrm{Mn}^{2+}$ in the PP1 was $73 \%$ and $51 \%$ at 15 and 90 days, respectively. The removal of $\mathrm{Mn}^{2+}$ in the PP2 within the 15 days was $82 \%$ and $52 \%$ at 90 days. The efficiency of $\mathrm{Mn}^{2+}$ removal in the columns of the PP1 was in the following order: $(\mathrm{CF} \approx 48 \pm 5 \%)>(\mathrm{SF} \approx 24 \pm 5 \%)>(\mathrm{GF}$ $\approx 8 \pm 1 \%)>(\mathrm{UVD} 1 \approx 3 \pm 1 \%)$ and for the $\mathrm{PP} 2:(\mathrm{CF} \approx$ $48 \pm 4 \%)>(\mathrm{ZF} \approx 38 \pm 5 \%)>(\mathrm{GF} \approx 11 \pm 3 \%)>(\mathrm{UVD} 1 \approx$ $4 \pm 2 \%$ ).

The removal of iron and manganese from rainwater using conventional adsorbents is attributed to some adsorption mechanisms of the filter bed (e.g. filtration, chemical and microbiological activity). At the beginning, the GF1 and GF2 columns reduce the $\mathrm{Fe}^{2+}$ and $\mathrm{Mn}^{2+}$ concentration but not below the maximum limits. After the second $(\mathrm{CF})$ and the third (SF and ZF), it was accomplished the $\mathrm{Fe}^{2+}$ and $\mathrm{Mn}^{2+}$ removal below the permissible limits. Particularly, the iron and manganese adsorption by zeolite and clays is promoted by ion exchange, electrostatic attraction considering the negative charge of their surfaces. Then, both zeolite and clay are commonly used 
for the removal of heavy metals and organic compounds, as well as being a medium for bacterial activity enhancement (Akhigbe et al. 2016) (Anbukumar and Kumar 2014).

The highest $\mathrm{Fe}^{2+}$ and $\mathrm{Mn}^{2+}$ removal was provided by CFs which is attributed to the oxygen provided to the column. Then, the higher dissolved oxygen and also the $\mathrm{pH}$ level over 7 during the system operation promote the $\mathrm{Fe}^{2+}$ and $\mathrm{Mn}^{2+}$ oxidation to the insoluble forms of $\mathrm{Fe}^{3+}$ and $\mathrm{Mn}^{4+}$. Then iron and manganese forms were adsorbed on the clay surface filter (Aziz et al. 2020). The insoluble $\mathrm{Fe}^{3+}$ and $\mathrm{Mn}^{4+}$ forms in the influent were efficiently removed by ZFs columns due to the adsorption to the zeolite surface. Particularly, the $\mathrm{Fe}^{3+}$ oxide form allow the formation of some iron complexes which are suspended and eliminated by biofiltration. It has been reported in previous work using a ceramic filter with efficiency higher than 50\% allowing the removal of $\mathrm{Fe}^{2+}$ cations (Tekerlekopoulou et al. 2013; y Zereffa and Bekalo 2017).

Clays and zeolites also make viable the elimination of contaminants existent in water by ion exchange mechanism between iron and manganese and the available cations existent in the minerals structure (Dashti et al. 2021). The negative charged surface of zeolite and clay can attract the positive charge of metal particles from water (Givehchi et al. 2015) which is an additional mechanism of metal ions removal. Then, the residence time of $3 \mathrm{~h}$ contributes for a higher removal due to the intimal contact between filter medium and the water flow (Baraee et al. 2016).

The slight removal found in the UVD stage may be promoted by the limited precipitation of the oxidized $\mathrm{Fe}^{3+}$, coming from the previous stages, into the insoluble $\mathrm{Fe}(\mathrm{OH})_{3}$. Even though, the presence of $\mathrm{Fe}(\mathrm{OH})_{3}$ content in the effluent was not verified in this study. However, a previous report about the use of an UV-ozone reactor for wastewater treatment determined an oxidation-precipitation mechanism for soluble iron $\left(\mathrm{Fe}^{2+}\right)$ allowing the nucleation and growth of $\mathrm{Fe}(\mathrm{OH})_{3}$ (Hanela et al. 2015).

The high error values reported in this study may be influenced by variations of some variables such as: oxygen flow provided to the ceramic filters, changes occurring during biofilm formation and the effect of the calibration (in-situ) of the water treatment system. Also, rainwater has variable composition since it was collected during the 90 days from the roof and runoff water of courtyard of house of the study area. The management of rainwater is critical due to several factors that determine their quality. Even in urban areas, there are many conditions that have limited the development of effective solutions for rainwater management (Zubala and Patro 2021). In rural areas, the case of the study area is difficult to control the collection conditions since some cultural and structural factors limit the improvement of inhabitant practices.

\section{Removal of microbial pollutants}

The existing fauna surround the houses of the inhabitants of the study area. So, birds and rodents' manure is commonly found in roof and courtyards of these houses, then the collected rainwater contains microorganisms of faecal origin that change the original quality of rainwater. It is a traditional practice of inhabitants the rainwater collection and consumption without having a treatment. After carrying out a characterization of the collected rainwater, the presence of total coliforms, faecal coliforms and Escherichia coli was verified as the most relevant microbiological pollutants.

The efficiency of total coliforms (TC), faecal coliforms (FC) and Escherichia Coli (E. coli) removal was determined at each stage of the treatment system as it is depicted in Fig. 8a, b and c. The efficiency of $E$. coli removal by column filters following this order: UVD $>\mathrm{ZF}>\mathrm{SF}>\mathrm{CF}>\mathrm{GF}$. Pilot plant PP1 removes TC until up to $69 \%$ in the first 15 days, but the efficiency decreased gradually until it was removed $49 \%$ at 90 days. The pilot plant PP 2 removed $70 \%$ and $51 \%$ of TC at 15 and 90 days, respectively. The PP2 developed the best efficiency for TC removal. The TC removal efficiency of by filter columns in the PP1 was in the following order: $(\mathrm{UVD} 1 \approx 57 \pm 9 \%)>(\mathrm{SF} \approx 46 \pm 4 \%)>(\mathrm{CF}$ $\approx 49 \pm 5 \%)>(\mathrm{GF} \approx 10 \pm 2 \%)$ and for the PP2: (UVD2 $\approx$ $63 \pm 7 \%)>(\mathrm{ZF} \approx 61 \pm 2 \%)>(\mathrm{CF} \approx 47 \pm 3 \%)>(\mathrm{GF} \approx$ $11 \pm 1 \%)$.

The removal of FC in the PP1 was $93 \%$ and $57 \%$ at 15 and 90 days, respectively. The removal of FC in the PP2 within the 45 days was $100 \%$ and then the efficiency decreases at $50 \%$ at 90 days. The efficiency of FC removal in the columns of the PP1 was in the following order: (UVD1 $\approx 81 \pm 15 \%)>(\mathrm{SF} \approx 20 \pm 5 \%)>(\mathrm{CF} \approx 23 \pm 3 \%)>(\mathrm{GF}$ $\approx 13 \pm 5 \%)$ and for PP2: (UVD2 $\approx 85 \pm 20 \%)>(\mathrm{ZF} \approx$ $46 \pm 8 \%)>(\mathrm{CF} \approx 24 \pm 3 \%)>(\mathrm{GF} \approx 15 \pm 6 \%)$.

The E. coli removal was efficient in both pilot plant PP1 and PP2. The PP1 reduced the $100 \%$ of E. coli within 45 days. After 90 days, the efficiency decreased reaching a $38 \%$ of E. coli removal. The PP2 also eliminated the $100 \%$ of E. coli within 60 days but later it was reduced at $50 \%$ within 90 days. The efficiency of $E$. coli removal in the columns in $\mathrm{PP} 1$ was $(\mathrm{UVD} 1 \approx 77 \pm 29 \%)>(\mathrm{SF} \approx 29 \pm 5 \%)>(\mathrm{CF}$ $\approx 34 \pm 7 \%)>(\mathrm{GF} \approx 22 \pm 5 \%)$ and for the PP2 (UVD2 $\approx$ $85 \pm 24 \%)>(\mathrm{ZF} \approx 47 \pm 8 \%)>(\mathrm{CF} \approx 39 \pm 7.4 \%)>(\mathrm{GF} \approx$ $23 \pm 9 \%)$.

The efficiency of the CFs column packed with ceramic spheres was due to the physical and mineralogical properties of raw clays. The main advantage using ceramic spheres is the porosity which is required for microscopic particles removal. The microscopic particles are originated from some physical processes like obstructions and inertia (Zereffa and Bekalo 2017). Raw clays promote the adsorption and inactivation of microorganisms. It has been reported that certain 

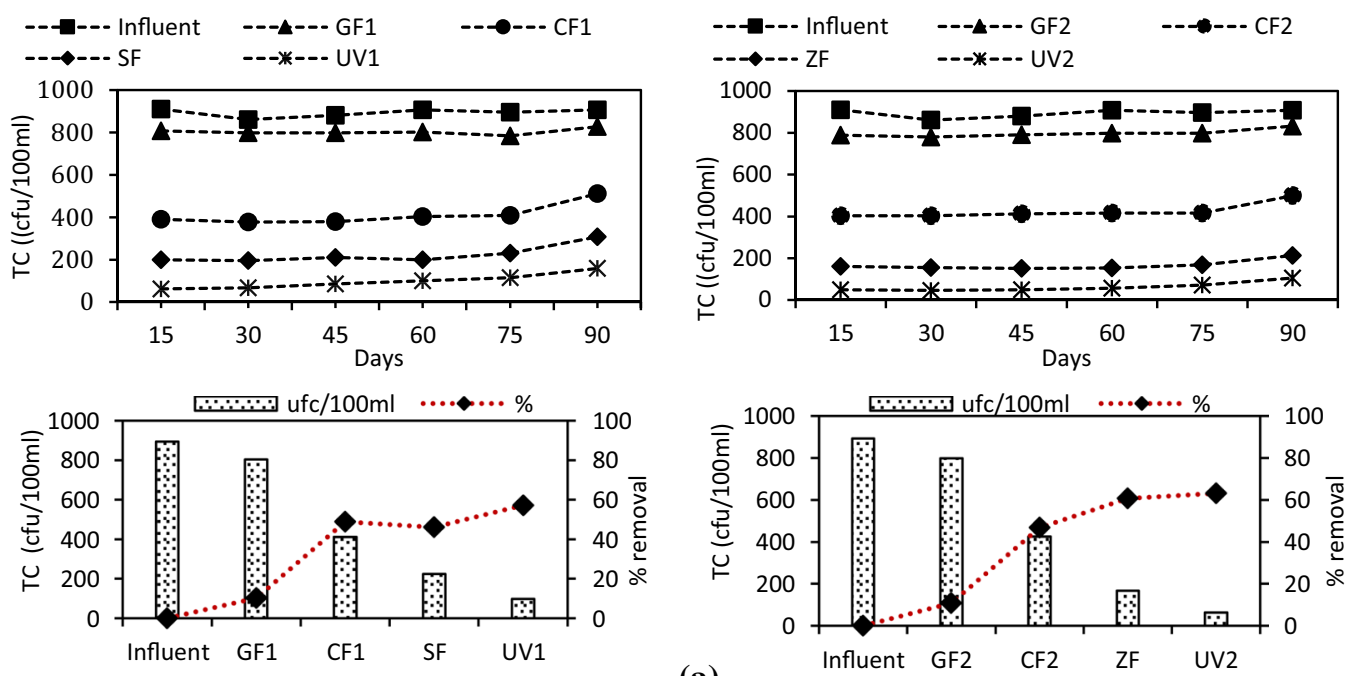

(a)
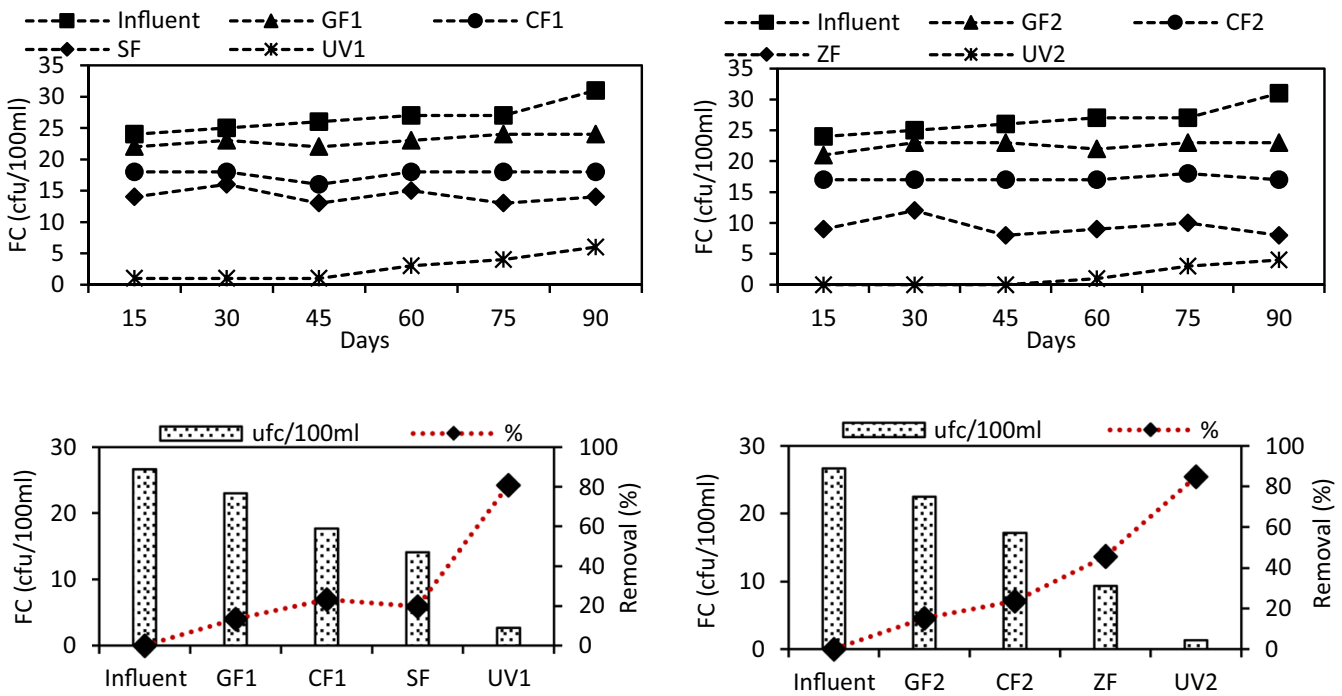

(b)
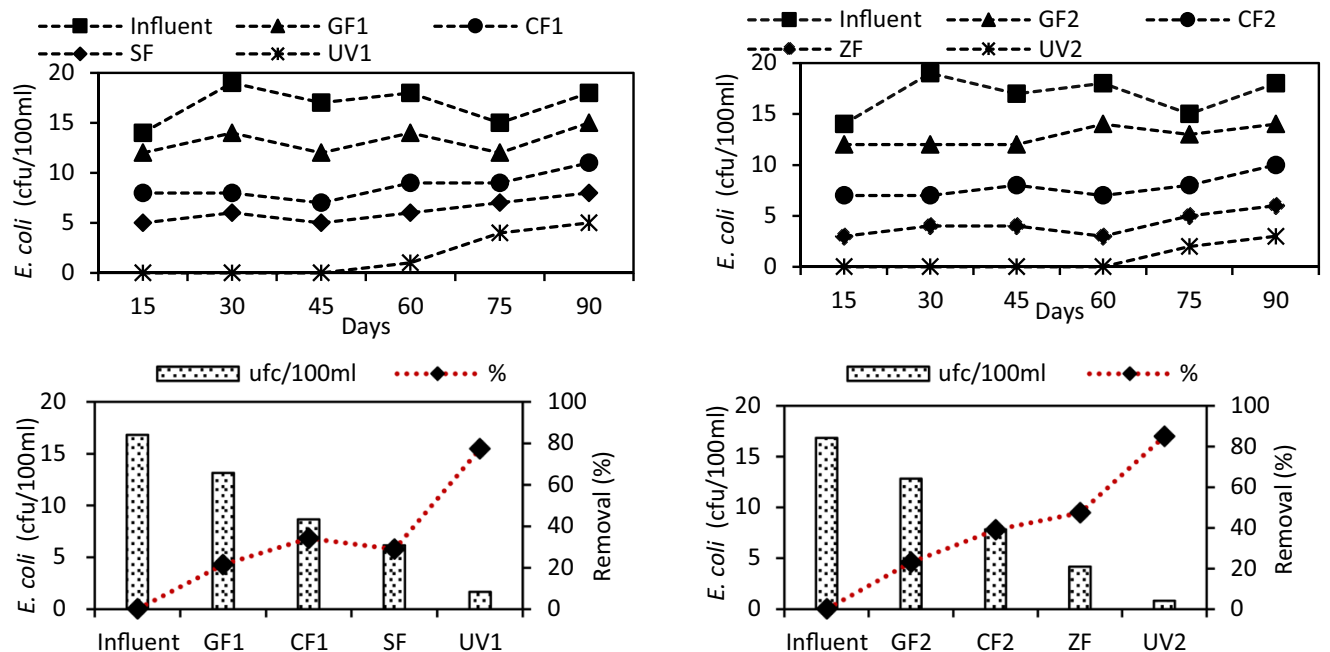

(c) 
4 Fig. 8 Trends in the removal behaviour of TC, FC and E. coli, over a period of 90 days, average removal and efficiency percentages of filter materials and UVD. a CT removal; b FC removal and c E. coli removal

clay minerals act as bactericidal agents that remove bacteria from the water. A typical raw clays used with this purposes are the illite $\left(\mathrm{K}, \mathrm{H}_{3} \mathrm{O}\right)(\mathrm{Al}, \mathrm{Mg}, \mathrm{Fe})_{2}(\mathrm{Si}, \mathrm{Al}){ }_{4} \mathrm{O}_{10}\left[(\mathrm{OH})_{2}\right.$, $\left(\mathrm{H}_{2} \mathrm{O}\right)$ ] (Kleyi et al. 2016; Unuabonah et al. 2018; Wang et al. 2017). Also, in raw clays, the quartz which is a tectosilicate improves the surface area for the ceramic material.

The content of silica, aluminium and ferric oxides in the raw clay promoted a bactericidal environment. As it has been reported, those compounds reduced the content of viruses, bacteria and protozoa (Asadishad et al. 2013; Brown and Sobsey 2009; Levett et al. 2018; London et al. 2017; Morrison et al. 2016). The raw clay $\mathrm{CZ}$ was transformed into ceramic spheres. The content of $\mathrm{Al}_{2} \mathrm{O}_{3}$ of ceramic spheres allowed an efficiently TC, FC and E. coli removal. The dissolution of the mineralogical phases of the clays and the solubility of the mineralogical phases depend of specific system conditions (e.g. pH, Eh, etc.) also were reported to enhance the microbial disinfection (London et al. 2017; Morrison et al. 2016). The main elements of the raw clays are $\mathrm{Al}, \mathrm{K}$, $\mathrm{Mg}, \mathrm{Fe}, \mathrm{Na}, \mathrm{Ca}$ and $\mathrm{Si}$, which can be transferred to the cell membrane of TC, FC and E. coli. Then, some complexation reactions may occur on the surface of the bacteria (Williams et al. 2011).

Also, TC, FC and E. coli could be removed by mechanical entrapment and some biological mechanisms that generate the superficial layer of the column. It is well known that some bacteria are trapped in the deepest bed of the column. This phenomenon has been reported to occur in slow sand filters with a $95 \%$ of removal of bacteria and viruses. The formation of a surface layer cake promotes the high efficiency removal of conventionally filtering materials (e.g. sand, clays, zeolites, etc.). This surface layer named: "schmutzedecke" is formed by living and dead material (Manz and Eng 2012; Mwabi et al. 2012). Then, it is necessary a flood layer of $50 \mathrm{~mm}$ to keep the biological layer or schmutzedecke alive. The schmutzedecke requires a continuous flood aquatic environment at constant flow and oxygenated (Lea 2014; Zhao et al. 2019). Lower thickness layer may affect the diffusion of oxygen and weaken the biological zone formed above the sand bed. Also, lower thickness layer disturbs the stability of the biolayer which produces a turbulence and detachment of the material. Also, other purification mechanisms such as predation, elimination, desorption and biooxidation are also presented for biological treatment (Haig et al. 2011). Even though, in this study we do not have evidence of the formation of this biofilm. The operational conditions used (e.g. aeration, low flow rate, flood layer at the top the column, etc.) have been established in order to allow the biological layer formation and operation.

The efficiency of the UVD system is due to the UV light. The UV light penetrates the cell wall of microorganisms and the radiation is adsorbed by the genetic material (DNA or RNA). Then, the ability of microorganisms to survive is damaged. So, the inactivation of microorganisms (inability to replicate) or cell death occurred (EPA 2002, 2014). The efficiency of the UVD system also depends on the characteristics of the water to be disinfected. The turbidity, suspended solids and colour influenced the disinfection process. Moreover, the UVD system with low pressure UV lamps lose their effectiveness in effluents with high suspended solids concentrations $(>30 \mathrm{mg} / \mathrm{L})$. The microorganism that reveal faecal contamination (e.g. E. Coli) are able to reactivate in both light and darkness environment, after being inactivated by UV light (Bohrerova et al. 2015). In general, bacteria could reactivate after a UV disinfection process.

The main problem is the presence of contaminants that pollute lamps and reduce the intensity affecting the absorbance or transmittance. Some other factors may disturb the lamps functioning (e.g. time of use, dirt coating, water particles evaporation, water hardness, alkalinity, lamp temperature, $\mathrm{pH}$, colour, turbidity, total suspended solids greater than $30 \mathrm{mg} / \mathrm{L}$, microorganisms, and the concentration of Fe, Mn and Ca) (Asano 2015).

It has been reported that UVD system efficiency depends on the operational conditions of the system (e.g. turbidity, $\mathrm{pH}$, pollutants content) (Cidecalli-Cp 2007). It could explain the results obtaining in our UVD stage for TC, FC and $E$. coli removal from the day 60 where the efficiency reduced may be due to the higher TDS and lower DO.

Besides, the pilot plant system operated in this study needs maintenance once it reached 45 days of functioning. Then, a backwash in the GFs and CFs was necessary to performed. Also, the removal of the surface sand layer from SF and ZF filters was performed. In the UVD system, the UV lamp tube was removed to clean the surface from dirt and water particles.

The production cost of the ceramic spheres was 0.45 cents per kilogram. So, it was estimated a cost of 1.80 USD to fill the entire column. The cost of gravel, sand and zeolite is 0.25 USD per kilogram that are collected in the area. Therefore, the cost of 1.25 USD was estimated for each one of the sand and zeolite columns. The cost of assemblage of the pilot system is 70.30 USD which includes the filling material for the three columns. The peristaltic pump cost is not considered. So, once the system is installed on site it will work by gravity. It is estimated that the pilot system will have 30 years of useful life because it was built with PVC materials. If it is necessary, the air pump can be replaced once a year with a cost of 4.75 USD per unit. Finally, a UV lamp costs 20 USD with $10,000 \mathrm{~h}$ of functioning. In rural 
Table 2 Comparison of treatment systems used for water decontamination purposes

\begin{tabular}{|c|c|c|c|c|}
\hline Type of water & Pollutants & System & Results & References \\
\hline Rainwater & $\mathrm{Fe}^{2+}, \mathrm{Mn}^{2+}, \mathrm{TC}, \mathrm{FC}$, E. coli & $\begin{array}{l}\text { Pilot plant scale } \\
\text { 1st stage: gravel filter } \\
\text { 2nd stage: clay sphere filter } \\
\text { 3rd stage: sand or zeolite } \\
\text { filter } \\
\text { 4th stage: UV disinfection }\end{array}$ & $\begin{array}{l}\text { Removal: } 80 \% \mathrm{Fe}^{2+}, 86 \% \\
\mathrm{Mn}^{2+}, 100 \% \mathrm{TC}, 100 \% \\
\mathrm{FC} \text { and } 100 \% \text { in } 45 \text { days } \\
\text { of operation without } \\
\text { maintenance }\end{array}$ & This study \\
\hline Aqueous environment & $\mathrm{Pb}^{2+}, \mathrm{Cu}^{2+}$ and $\mathrm{Zn}^{2+}$ & Natural zeolite & $\begin{array}{l}\text { Zeolites are potential adsor- } \\
\text { bents for metal ions }\end{array}$ & Dashti et al. (2021) \\
\hline $\begin{array}{l}\text { Rainwater harvesting } \\
\text { system }\end{array}$ & $\begin{array}{l}\mathrm{NO}_{2}^{-}, \mathrm{TP}, \mathrm{PO}_{4}{ }^{3-}, \mathrm{K}^{+} \text {and } \\
\mathrm{Cl}^{-}\end{array}$ & - & $\begin{array}{l}\text { Rainwater is loaded by } \\
\text { heavy metals, aromatic } \\
\text { hydrocarbons with high } \\
\text { ability to accumulate }\end{array}$ & Zubala and Patro (2021) \\
\hline Groundwater & $\mathrm{Fe}^{2+}$ and $\mathrm{Mn}^{2+}$ & $\begin{array}{l}\text { Limestone filter assisted } \\
\text { with iron oxidized bacte- } \\
\text { ria at laboratory scale }\end{array}$ & $\begin{array}{l}\text { Removal: } 82 \% \mathrm{Fe}^{2+}, 84 \% \\
\underset{\mathrm{Mn}^{2+}}{ }\end{array}$ & Aziz et al. (2020) \\
\hline Rainwater & $\mathrm{COD}, \mathrm{Fe}, \mathrm{Mn}, \mathrm{Zn}, \mathrm{Cd}, \mathrm{Pb}$ & $\begin{array}{l}\text { Photo-electric-catalytic } \\
\text { (PEC) process Ti/TiO2 } \\
\text { NTs anode }\end{array}$ & $\begin{array}{l}\text { Photo-oxidation of } \mathrm{Fe}, \mathrm{Pb} \\
\text { and } \mathrm{Mn} \text {, and precipitation } \\
\text { for } \mathrm{Cd}, \mathrm{Pb}, \mathrm{Zn}\end{array}$ & Ebraheim et al. (2021) \\
\hline
\end{tabular}

homes of Amazon have electric power, so the incorporation of these treatment pilot systems is viable. Also, the rainwater treatment system of this study may be an interesting alternative for implementing in rural areas of developing countries where there is no access to safe water sources.

Once, we have widely discussed the results of our study; now we analysed these results in comparison with some other which are related to this field, according to the description of Table 2 .

This study is performed in pilot plant scale in comparison with other that are performed at laboratory or computational scale; however, in most of them there is a good efficiency for the removal of heavy metal included $\mathrm{Fe}^{2+}$ and $\mathrm{Mn}^{2+}$. In fact, it is not possible to compare meticulously studies because each one is performed in different operational conditions. Conversely our system reached similar removal efficiencies to those one obtained by the limestone filter assisted with iron oxidized bacteria at laboratory scale. Both, iron and manganese metal cations removal was efficiently performed due to the optimal configuration used in this study. Besides, the microbial (e.g. TC, FC and E. coli) also was performed providing a good quality water according to the permissible limit for drinking water standard.

\section{Conclusion}

In this study, it has been evaluated within 90 days two-pilot plants assembled using natural filtering materials for rainwater treatment. The collected rainwater characterization determined iron $\left(\mathrm{Fe}^{2+}\right)$, manganese $\left(\mathrm{Mn}^{2+}\right)$, total coliforms (TC), faecal coliforms (FC) and Escherichia coli (E. coli) as the main chemical and microbiological pollutants. The pilot plants consist of a first stage packing with crushed gravel. The second stage was packed using ceramic spheres. The third stage was packed using silica sand in the first pilot plant configuration and natural zeolite for the second one. Al last, it was incorporated a stage of ultraviolet disinfection (UVD for microbiological treatment. The sphere clay column was a strategic filter stage which allows the highest removal of pollutants on both configuration systems (PP1 and PP2). The configuration of the pilot plan system PP2, containing zeolite in the third stage, contributes to higher $\mathrm{Fe}^{2+}(42 \%)$ and $\mathrm{Mn}^{2+}(43 \%)$ removal in comparison with this stage in PP1, reaching contents below the permissible limits within the 45 days of operation. The configuration PP2 also provided higher microbial disinfection rates in comparison to PP1, where the UVD stage reached the removal of TC $(63 \%)$, FC (85\%), E. coli $(85 \%)$ within 45 days. Then, maintenance of water treatment systems was performed after 45 days of continuous operation. The backwash and cleaning of the gravel, clays spheres, sand and zeolite filters were performed along with the cleaning of UV lamp tube. Then the water treatment systems of this study can be implemented in rural areas of developing countries with no access to safe water. The availability, low cost and quickly assembling of the filtering materials is a feasible alternative for treatment purposes. Besides, the easy operation and maintenance of this treatment systems do not require complex training for inhabitants to ensure continuous water supply.

Acknowledgements The authors wish to thank all who assisted in conducting this work.

Author contribution EP: Investigation, Writing-Original Draft; Writing-Review \& Editing; Visualization, Project administration, Funding acquisition/DG: Methodology, Validation, Writing_-Original Draft; 
Data Curation; Formal analysis; Writing-Review \& Editing/GR: Investigation, Writing-Original Draft; Data Curation/MJGR: Conceptualization, Writing - Review \& Editing, Supervision, Visualization/FO: Conceptualization, Writing - Review \& Editing, Supervision, Visualization.

Funding Funding for open access charge: Universidad de Granada / CBUA. No funding was received for conducting this study.

\section{Declarations}

Conflict of interest The authors have no conflicts of interest to declare that are relevant to the content of this article.

Open Access This article is licensed under a Creative Commons Attribution 4.0 International License, which permits use, sharing, adaptation, distribution and reproduction in any medium or format, as long as you give appropriate credit to the original author(s) and the source, provide a link to the Creative Commons licence, and indicate if changes were made. The images or other third party material in this article are included in the article's Creative Commons licence, unless indicated otherwise in a credit line to the material. If material is not included in the article's Creative Commons licence and your intended use is not permitted by statutory regulation or exceeds the permitted use, you will need to obtain permission directly from the copyright holder. To view a copy of this licence, visit http://creativecommons.org/licenses/by/4.0/.

\section{References}

Ajayi BA, Lamidi YD (2015) Formulation of ceramic water filter composition for the treatment of heavy metals and correction of physiochemical parameters in household water. Art Des Rev 03(04):94-100. https://doi.org/10.4236/adr.2015.34013

Akhigbe L, Ouki S, Saroj D (2016) Disinfection and removal performance for Escherichia coli and heavy metals by silver-modified zeolite in a fixed bed column. Chem Eng J 295:92-98. https://doi. org/10.1016/j.cej.2016.03.020

Anbukumar S, Kumar A (2014) Effluent treatment for sago industry using zeolite and activated carbon. Open J Water Pollut Treat 2014(2):18-26. https://doi.org/10.15764/wpt.2014.02003

Asadishad B, Ghoshal S, Tufenkji N (2013) Short-term inactivation rates of selected gram-positive and gram-negative bacteria attached to metal oxide mineral surfaces: role of solution and surface chemistry. Environ Sci Technol 47(11):5729-5737. https:// doi.org/10.1021/es4003923

Asano T (2015) Water reuse issues, technologies, and applications. Metcalf \& Eddy, Inc., McgrawHill Education, New York, USA

ASTM D 4318 (2016) Límite líquido, límite de plástico, y el índice de plasticidad de los suelos. Appl Clay Sci 29(2):1302-1306

Aziz HA, Tajarudin HA, Wei THL, Alazaiza MYD (2020) Iron and manganese removal from groundwater using limestone filter with iron-oxidized bacteria. Int J Environ Sci Technol 17(5):26672680. https://doi.org/10.1007/s13762-020-02681-5

Baraee I, Mehdi Borghei S, Takdastan A, Hasani AH, Javid AH (2016) Performance of biofilters in GAC-sand and anthracite-sand dualmedia filters in a water treatment plant in Abadan, Iran. Desalination Water Treat 57(42):19655-19664. https://doi.org/10.1080/ 19443994.2015.1101715

Bohrerova Z, Rosenblum J, Linden KG (2015) Importance of recovery of E. coli in water following ultraviolet light disinfection. J
Environ Eng 141(6):04014094. https://doi.org/10.1061/(asce)ee. 1943-7870.0000922

Brown J, Sobsey MD (2009) Ceramic media amended with metal oxide for the capture of viruses in drinking water. Environ Technol 30(4):379-391. https://doi.org/10.1080/09593330902753461

Carlos LM, Torres FM, López NG, Rueda MBC (2007) Pueblos indígenas, desarrollo humano y discriminación en el ecuador. Universidad Andina Simón Bolivar, Quito, Abya-Yala

CAWST (2011) Introducción al tratamiento del agua a nivel domiciliario y su almacenamiento seguro, pp 1-270

Chidamba L, Korsten L (2015) A scoping study on the prevalence of Escherichia coli and Enterococcus species in harvested rainwater stored in tanks. Water SA 41(4):501-508. https://doi.org/10.4314/ wsa.v41i4.09

Cidecalli-Cp (2007) Diseño de captación del agua de lluvia, (Colpos 1), 55

Dammak N, Fakhfakh N, Fourmentin S, Benzina M (2013) Natural clay as raw and modified material for efficient o-xylene abatement. $\mathrm{J}$ Environ Chem Eng 1(4):667-675. https://doi.org/10.1016/j.jece. 2013.07.001

Dashti A, Amirkhani F, Jokar M, Mohammadi AH, Chau K-W (2021) Insights into the estimation of heavy metals ions sorption from aqueous environment onto natural zeolite. Int J Environ Sci Technol 18(7):1773-1784. https://doi.org/10.1007/ s13762-020-02912-9

Ebraheim G, Karbassi AR, Mehrdadi N (2021) Employing speciation of metals to assess photo-assisted electrochemical efficiency for improving rainwater quality in Tehran, Iran. Int J Environ Sci Technol. https://doi.org/10.1007/s13762-021-03127-2

EPA (2002) Onsite wastewater treatment system manual. Environmental Protection, (February), vol EPA/625/R-00/008, pp 1-367

EPA (2014) Primer for municipal wastewater treatment systems. Master Thesis 22(January):55

EPA, Environmental Protection Agency (2018) Harmful algal blooms. https://www.epa.gov/nutrientpollution/harmful-algal-blooms. Accessed 15 Mar 2021

Givehchi R, Li Q, Tan Z (2015) The effect of electrostatic forces on filtration efficiency of granular filters. Powder Technol 277:135140. https://doi.org/10.1016/j.powtec.2015.01.074

Haig SJ, Collins G, Davies RL, Dorea CC, Quince C (2011) Biological aspects of slow sand filtration: past, present and future. Water Sci Technol Water Supply 11(4):468-472. https://doi.org/ 10.2166/ws.2011.076

Hanela S, Durán J, Jacobo S (2015) Removal of iron-cyanide complexes from wastewaters by combined UV-ozone and modified zeolite treatment. J Environ Chem Eng 3(3):1794-1801. https:// doi.org/10.1016/j.jece.2015.06.023

Jesmi Y, Mujeeb Rahiman KM, Hatha AAM, Deepu L, Jyothi S (2014) Risk assessment of rooftop-collected rainwater for individual household and community use in central Kerala, India. J Environ Health 76:114-121. https://doi.org/10.1108/17506 200710779521

Jokisch B, Mcsweeney K (2006) Informe sobre los resultados del diagnóstico de la situación de salud de las nacionalidades shuar y achuar

Khadse GK, Lande VW, Andey SP, Labhasetwar PK (2013) Performance of up-flow roughing biofilter in iron removal from groundwater. Int J Water Resour Arid Environ 2(1):9-14

Kim Y, Dao AD, Kim M, Nguyen VA, Han M (2017) Design and management of rainwater harvesting systems to control water quality for potable purposes in $\mathrm{Cu}$ Khe, Vietnam. Water Sci Technol Water Supply 17(2):452-460. https://doi.org/10.2166/ws.2016. 154

Kleyi PE, Ray SS, Abia ALK, Ubomba-Jaswa E, Wesley-Smith J, Maity A (2016) Preparation and evaluation of quaternary imidazolium-modified montmorillonite for disinfection of drinking 
water. Appl Clay Sci 127-128:95-104. https://doi.org/10.1016/j. clay.2016.04.012

Köppen W, Geiger R (1936) Das geographische system der klimate

Lea M (2014) Biological sand filters: low-cost bioremediation technique for production of clean drinking water. Curr Protoc Microbiol. https://doi.org/10.1002/9780471729259.mc01g01s33

Lee JY, Kim H, Han M (2016) Importance of maintenance in rainwater harvesting systems: a case study. Water Sci Technol Water Supply 16(1):97-103. https://doi.org/10.2166/ws.2015.115

Levett A, Gagen EJ, Diao H, Guagliardo P, Rintoul L, Paz A, Vasconcelos PM, Southam G (2018) The role of aluminium in the preservation of microbial biosignatures. Geosci Front. https://doi. org/10.1016/j.gsf.2018.06.006

Londono SC, Hartnett HE, Williams LB (2017) Antibacterial activity of aluminum in clay from the Colombian Amazon. Environ Sci Technol 51(4):2401-2408. https://doi.org/10.1021/acs.est.6b046 70

Manz D, Eng P (2012) Slow sand filtration-demand operated and cleaned using backwash, (March), 1-3

Masschelein WJ (2012) Ultraviolet light in water and wastewater sanitation. עטרנה זרלע Vol 66

Millipore (2018) Microbial growth media selection guide. Microbial Growth Media, Darmstadt, Germany

Morrison KD, Misra R, Williams LB (2016) Unearthing the antibacterial mechanism of medicinal clay: a geochemical approach to combating antibiotic resistance. Sci Rep 6(1):19043. https://doi. org/10.1038/srep19043

Mwabi JK, Mamba BB, Momba MNB (2012) Removal of Escherichia coli and faecal coliforms from surface water and groundwater by household water treatment devices/systems: a sustainable solution for improving water quality in rural communities of the Southern African development community region. Int J Environ Res Public Health 9(12):139-170. https://doi.org/10.3390/ijerph9010139

Naddeo V, Scannapieco D, Belgiorno V (2013) Enhanced drinking water supply through harvested rainwater treatment. J Hydrol 498:287-291. https://doi.org/10.1016/j.jhydrol.2013.06.012

NTE INEN 1108 (2014) Norma técnica ecuatoriana NTE INEN 1108, Quinta revisión

Patil SA, Harnisch F, Koch C, Hübschmann T, Fetzer I, CarmonaMartínez AA, Müller S, Schröder U (2011) Electroactive mixed culture derived biofilms in microbial bioelectrochemical systems: the role of $\mathrm{pH}$ on biofilm formation, performance and composition. Bioresour Technol 102(20):9683-9690. https://doi.org/10. 1016/j.biortech.2011.07.087

Pineda EP, Guaya D, Tituana C, Osorio F, García-Ruiz MJ (2020) Biochar from agricultural by-products for the removal of lead and cadmium from drinking water. Water (switzerland) 12(10):1-16. https://doi.org/10.3390/w12102933

Pineda E, García-Ruiz MJ, Guaya D, Manrique J, Osorio F (2021) Elimination of total coliforms and Escherichia coli from water by means of filtration with natural clays and silica sand in developing countries. Environ Geochem Health 43(1):195-207. https://doi. org/10.1007/s10653-020-00623-1

Qian J, Qu K, Tian B, Zhang Y (2021) Water treatment of polluted rivers in cities based on biological filter technology. Environ Technol Innov 23:101544. https://doi.org/10.1016/j.eti.2021.101544

Ren D, Smith JA (2013) Retention and transport of silver nanoparticles in a ceramic porous medium used for point-of-use water treatment. Environ Sci Technol 47(8):3825-3832. https://doi.org/10. 1021/es4000752

Rodell M, Famiglietti JS, Wiese DN, Reager JT, Beaudoing HK, Landerer FW, Lo MH (2018) Emerging trends in global freshwater availability. Nature 557(7707):651-659. https://doi.org/10.1038/ s41586-018-0123-1
Semiz B (2017) Characteristics of clay-rich raw materials for ceramic applications in Denizli region (Western Anatolia). Appl Clay Sci 137:83-93. https://doi.org/10.1016/j.clay.2016.12.014

Shaheed R, Wan Mohtar WHM, El-Shafie A (2017) Ensuring water security by utilizing roof-harvested rainwater and lake water treated with a low-cost integrated adsorption-filtration system. Water Sci Eng 10(2):115-124. https://doi.org/10.1016/j.wse.2017. 05.002

Souza RPA, Motta FV, Carvalho RG, Acchar W, Harima E, Maribondo R, Paskocimas CA (2014) Obtaining ceramic filter from rice husk and kaolinitic clay. Mater Sci Forum 802:232-238

Sustainable T, Goals D (2019) The sustainable development goals report

Taffere GR, Beyene A, Vuai SAH, Gasana J, Seleshi Y (2017) Dilemma of roof rainwater quality: applications of physical and organic treatment methods in a water scarce region of Mekelle, Ethiopia. Urban Water J 14(5):460-466. https://doi.org/10.1080/1573062X. 2016.1176225

Tekerlekopoulou AG, Pavlou S, Vayenas DV (2013) Removal of ammonium, iron and manganese from potable water in biofiltration units: a review. J Chem Technol Biotechnol 88(5):751-773. https://doi.org/10.1002/jctb.4031

Thomas O, Burgess C (2013) UV-visible spectrophotometry of water and wastewater. J Chem Inf Model 53(9):1689-1699

Unuabonah EI, Ugwuja CG, Omorogie MO, Adewuyi A, Oladoja NA (2018) Clays for efficient disinfection of bacteria in water. Appl Clay Sci 151(April 2017):211-223. https://doi.org/10.1016/j.clay. 2017.10.005

Wang X, Dong H, Zeng Q, Xia Q, Zhang L, Zhou Z (2017) Reduced iron-containing clay minerals as antibacterial agents. Environ Sci Technol 51(13):7639-7647. https://doi.org/10.1021/acs.est. $7 \mathrm{~b} 00726$

Wang Z, Zhong MG, Wan JF, Xu GJ, Liu Y (2016) Development of attapulgite composite ceramsite/quartz sand double-layer biofilter for micropolluted drinking source water purification. Int J Environ Sci Technol 13(3):825-834. https://doi.org/10.1007/ s13762-015-0920-0

WHO (2017) WHO_-guidelines on drinking water quality—fourth edition

Williams LB, Metge DW, Eberl DD, Harvey RW, Turner AG, Prapaipong P, Poret-Peterson AT (2011) What makes a natural clay antibacterial? Environ Sci Technol 45(8):3768-3773. https://doi. org/10.1021/es1040688

Yuan G, Theng B, Churchman G, Gates W (2013) Clays and clay minerals for pollution control. In: Bergaya F, Lagaly G (eds) Handbook of clay science, Part B: techniques and applications, Chap 5.1, vol 5. Elsevier, The Netherlands, pp 587-644

Zereffa EA, Bekalo TB (2017) Clay ceramic filter for water treatment. Mater Sci Appl Chem 34(1):69-74. https://doi.org/10.1515/ msac-2017-0011

Zhao Y, Wang X, Liu C, Wang S, Wang X, Hou H, Wang J, Li H (2019) Purification of harvested rainwater using slow sand filters with low-cost materials: bacterial community structure and purifying effect. Sci Total Environ 674:344-354. https://doi.org/10.1016/j. scitotenv.2019.03.474

Zhu K, Zhang L, Hart W, Liu M, Chen H (2004) Quality issues in harvested rainwater in arid and semi-arid Loess Plateau of northern China. J Arid Environ 57(4):487-505. https://doi.org/10.1016/ S0140-1963(03)00118-6

Zubala T, Patro M (2021) Time and spatial variability in concentrations of selected pollutants in the new bypass rainwater harvesting system. Water Air Soil Pollut 232(5):211. https://doi.org/10.1007/ s11270-021-05138-8 